National Water-Quality Assessment Program

\title{
Preliminary Estimates of Annual Agricultural Pesticide Use for Counties of the Conterminous United States, 2010-2011
}

Open-File Report 2013-1295 



\section{Preliminary Estimates of Annual Agricultural Pesticide Use for Counties of the Conterminous United States, 2010-2011}

By Nancy T. Baker and Wesley W. Stone

National Water-Quality Assessment Program

Open-File Report 2013-1295 


\title{
U.S. Department of the Interior SALLY JEWELL, Secretary
}

\section{U.S. Geological Survey Suzette M. Kimball, Acting Director}

\author{
U.S. Geological Survey, Reston, Virginia: 2013
}

For more information on the USGS - the Federal source for science about the Earth, its natural and living resources, natural hazards, and the environment, visit http://www.usgs.gov or call 1-888-ASK-USGS.

For an overview of USGS information products, including maps, imagery, and publications, visit http://www.usgs.gov/pubprod

To order this and other USGS information products, visit http://store.usgs.gov

Any use of trade, firm, or product names is for descriptive purposes only and does not imply endorsement by the U.S. Government.

Although this information product, for the most part, is in the public domain, it also may contain copyrighted materials as noted in the text. Permission to reproduce copyrighted items must be secured from the copyright owner.

Suggested citation:

Baker, N.T., and Stone, W.W., 2013, Preliminary estimates of annual agricultural pesticide use for counties of the conterminous United States, 2010-11: U.S. Geological Survey Open-File Report, 2-p. pamphlet, 14 tables, http://dx.doi.org/10.3133/ofr20131295

ISSN 2331-1258 (online 


\section{Contents}

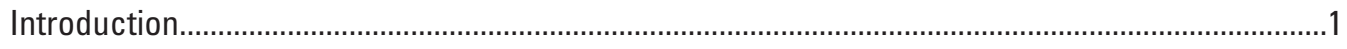

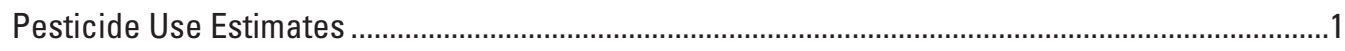

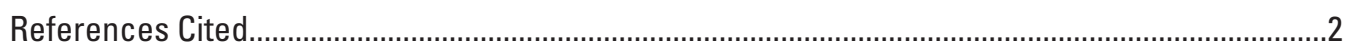





\title{
Preliminary Estimates of Annual Agricultural Pesticide Use for Counties of the Conterminous United States, 2010-2011
}

\author{
By Nancy T. Baker and Wesley W. Stone
}

\section{Introduction}

This report provides preliminary estimates of annual agricultural use of 374 pesticide compounds in counties in the conterminous United States in 2010 and 2011. The files provided are a continuation of the 1992-2009 pesticide use estimates reported by Stone (2013). Estimates for 2010 and 2011 will be revised upon availability of updated crop acreages in the 2012 Agricultural Census, to be published by the U.S. Department of Agriculture (USDA) in 2014. Because the updated crop acreages will also affect pesticide use estimates previously reported for 2008 and 2009 in Stone (2013), revised estimates for those years will be included in the forthcoming updated publication.

\section{Pesticide Use Estimates}

Pesticide use for 2010 and 2011 was estimated by means of the methods described in Thelin and Stone (2013). As described in Thelin and Stone (2013), USDA county-level data for harvested-crop acreage were used in conjunction with proprietary Crop Reporting District (CRD)-level pesticide-use data to estimate county-level pesticide use. Two different methods, EPest-low and EPest-high, were used to estimate a range of use, with the exception of estimates for California, which were taken from annual Department of Pesticide Regulation Pesticide Use Reports (Thelin and Stone, 2013). Both methods incorporated surveyed and extrapolated rates to estimate pesticide use for counties, but EPest-low and EPest-high estimation procedures differed in how they treated situations when a CRD was surveyed and pesticide use was not reported for a particular pesticide-by-crop combination. If use of a pesticide on a crop was not reported in a surveyed CRD, EPest-low reports zero use in the CRD for that pesticide-by-crop combination. EPest-high, however, treats the unreported use for that pesticide-by-crop combination in the CRD as unsurveyed, and pesticide-by-crop use rates from neighboring CRDs-and, in some cases, CRDs within the same USDA Farm Resource Region-are used to calculate the pesticide-by-crop EPest-high rate for the CRD (Thelin and Stone, 2013). Estimates for California were obtained from the online Department of Pesticide Regulation-Pesticide Use Reporting (DPR-PUR) database (California Department of Pesticide Regulation, 2012). These estimates were merged by crop with the EPest-low and EPesthigh county data after the estimation process was completed for the rest of the Nation. EPest-low and EPest-high estimates for California are the same.

USDA county-level harvested-crop acreage was obtained from Census of Agriculture and National Agricultural Statistics Service (NASS) crop surveys. The Census of Agriculture lists harvested acreages for numerous crops and is published every 5 years, 2007 being the most recently available. NASS publishes acreages for a few major crops every year. NASS acreage values were used for interim census years for crops with published data. For the 1992-2009 estimates (Stone, 2013), acreages for crops not published by NASS were interpolated linerarly between census years. For the Stone (2013) dataset, acreages for 2008 and 2009 were estimated by carrying 2007 Census of Agriculture acreages forward for those crops not listed by NASS. This method was also used for the 2010 and 2011 estimates published herein. When the 2012 Census of Agriculture data are published in early 2014, estimates for 2010 and 2011 (and for the previously published 2008 and 2009 estimates (Stone, 2013)) will be revised by using linear interpolation between 2007 and 2012 for crop acreages not listed by NASS.

Estimates of annual agricultural pesticide use are provided via this report as downloadable, tab-delimited files, which are organized by compound, year, state Federal Information Processing Standard (FIPS) code, county FIPS code, and $\mathrm{kg}$ (amount in kilograms). 


\section{References Cited}

California Department of Pesticide Regulation, 2010, Pesticide use reporting (PUR): Sacramento, Calif., Department of Pesticide Regulation, accessed June 2013 at http://www.cdpr.ca.gov/docs/pur/purmain.htm.

Thelin, G.P., and Stone, W. W., 2013, Estimation of annual agricultural pesticide use for counties of the conterminous United States, 1992-2009: U.S. Geological Survey Scientific Investigations Report 2013-5009, 54 p.

Stone, W.W., 2013, Estimated annual agricultural pesticide use for counties of the conterminous United States, 1992-2009: U.S. Geological Survey Data Series 752, 1-p. pamphlet, 14 tables. 

